\title{
Particle capture and deposition by deep-sea sponges from the Norwegian-Greenland Sea
}

\author{
Ursula Witte $^{1, *}$, Torleiv Brattegard ${ }^{2}$, Gerhard Graf ${ }^{3}$, Barbara Springer $^{1}$ \\ ${ }^{1}$ GEOMAR Research Center, Department for Environmental Geology, Wischhofstr. 1-3, D-24148 Kiel, Germany \\ ${ }^{2}$ University of Bergen, Department of Fisheries and Marine Biology, Hoyteknologisenteret, N-5020 Bergen, Norway \\ ${ }^{3}$ University oi Rostock, Department of Marine Biology, Freiligrathstr. 7/8, D-18055 Rostock, Germany
}

\begin{abstract}
Particle uptake and deposition by the 2 most abundant deep-sea demosponge species from the Norwegian and Greenland Sea (Thenea abyssorum) and the deep fjords of western Norway (Thenea muricata) were studied in flume experiments. Fluorescent particles of 1,2, 3,6, 10 and $16 \mu \mathrm{m}$ diameter (microspheres, Duke Scientific Corporation ${ }^{(1)}$ ) with a density of $1.05 \mathrm{~g} \mathrm{~cm}^{-3}$ were used at 2 current velocities, 1.5 and $5 \mathrm{~cm} \mathrm{~s}^{-1}$ Both species ingested small particles exclusively $(<6 \mu \mathrm{m}$ and $<10 \mu \mathrm{m}$, respectively), with a preference for the smallest fraction at both current speeds. The results suggest that the size spectrum actually ingested depends on the supplied particle sizes rather than on current velocity. Current velocity fields around dead specimens were recorded and turbulence intensity calculated in order to determine the influence of the sponge acting as a biogenic structure on the near-bottom current regime. Disruption of flow conditions was detected as far as $14 \mathrm{~cm}$ downstream and several $\mathrm{cm}$ laterally from the biogenic obstacles. Bulk biodeposition rates calculated from sponge biomass and volume of ingested particles range between 7 and $10 \mathrm{mg} \mathrm{d}^{-1} \mathrm{~g}^{-1}$ ash-free dry weight.
\end{abstract}

KEY WORDS: Deep sea - Sponge - Suspension feeding · Biodeposition - Biogenic structure Flow regime

\section{INTRODUCTION}

Most benthic communities in deeper waters rely on particles in the bottom nepheloid layer (BNL) for food The composition and abundance of these particles depend on a variety of processes, and field studies have revealed a high particle exchange between sediments and BNL. Particles may have rather short residence times in the BNL (Bacon \& van der Loeff 1989) but re-enter the benthic resuspension loop several times (for review see Graf \& Rosenberg in press). As even slow near-bottom current velocities exceed high sedimentation rates, these particles form a laterally moving flux situated high above many benthic organisms. Among the processes driving the suspension/ deposition loop are bioresuspension and biodeposition: deposit feeders build pits that mediate enhanced deposition (Yager et al. 1993) and epibenthic suspen-

·E-mail: uwitte@geomar.de sion feeders like sponges extract drifting particles from the water and - by expelling faeces or pseudofaecesmake them available for other benthic organisms.

In the deep sea, however, suspension feeders markedly decrease in overall importance with depth due to the scarcity of water-borne particles, and suspension feeding consequently is of much less importance in abyssal benthic communities than in energetic coastal habitats (Gage \& Tyler 1991). Deep-sea members of taxa hitherto believed to be suspension feeders have even been found to be carnivorous: the Sorberacea among the tunicates (Monniot \& Monniot 1978), now categorized as a separate class, the septibranch mollusc Cuspidaria (Reid \& Reid 1974) and members of the family Cladorhizidae in sponges, discovered only recently (Vacelet \& Boury-Esnault 1995).

In polar deep seas, on the other hand, sponges seem to dominate the epibenthic megafauna. The composition and distribution of sponge associations of the abyssal Norwegian and Greenland Sea have been studied by Barthel \& Tendal (1993), who were able to 


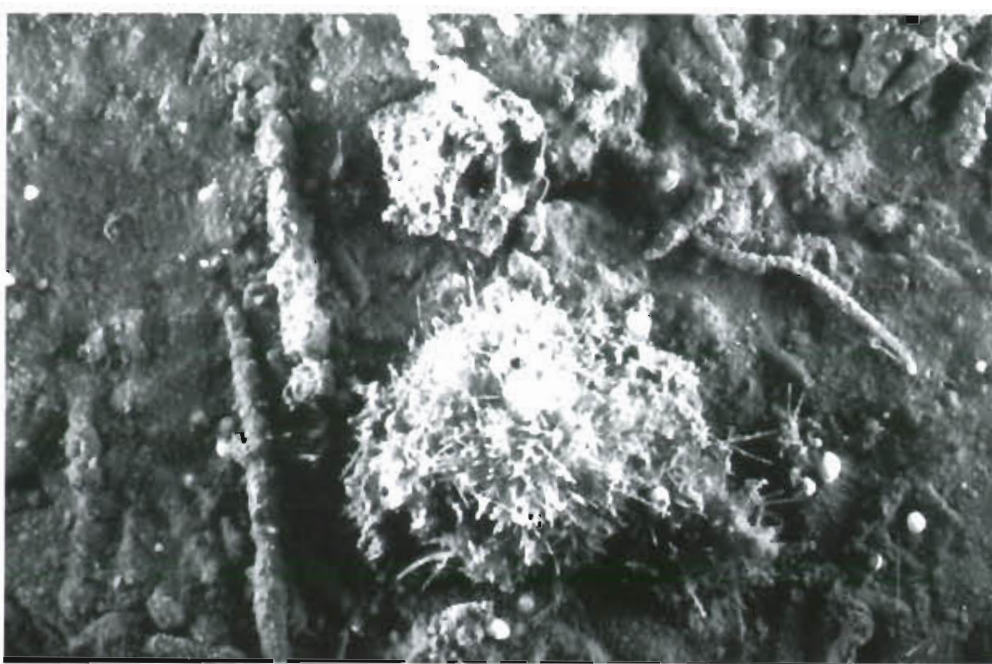

Fig. 1 Thenea abyssorum in its natural position half buried in the sediment Diameter of specimen $1.8 \mathrm{~cm}$

abundant that it is used as a character species in Arctic areas (Paul \& Menzies 1974), and it was the most abundant species at all stations sampled for this study in the deep Norwegian and Greenland Seas. The individuals are small, with a diameter of up to $2.5 \mathrm{~cm}$, and colonize soft bottoms exclusively. The sponges live half buried in the sediment (see Fig. 1), and are anchored in the sediment with a spicule root tuft that can be longer than the animal's height. In- and exhalant openings lie on opposite sides of the sponge above the sediment and can be surrounded by a screen of several-millimeter-long spicules. The angle of the spicules in this corona is variable. In the lab, the animals were observed to contract at irregular intervals, reducing their volume to ca $50 \%$. Together with contraction and closure of the spicule corona, this

delineate a core association of 8 regularly occurring sponge species that is distributed throughout the deep Norwegian and. Greenland Sea. Its most abundant species, the demosponge Thenea abyssorum, is used as a character species in some high Arctic areas (Paul \& Menzies 1974) and at many stations comprised more than $50 \%$ of the individuals of all taxa caught in trawls (Witte unpubl.). It can thus be expected to play a major role in exchange processes at the sediment/water interface.

For the first time, flume experiments with living deep-sea sponges have been performed to investigate the nutrition of 2 dominant species, Thenea abyssorum and Thenea muricata. In this paper, data on particle size preferences, clearance rates and the fate of ingested particles are presented. The small scale flow regime around sponge specimens is depicted to illuminate mechanisms of particle capture, and bulk deposition rates are calculated to gain insight into the role of this sponge community in exchange processes at the sediment/water interface.

\section{MATERIALS AND METHODS}

\section{Species descriptions}

Thenea abyssorum Koltun, 1959

Thenea abyssorum is part of the core association dominating the poriferan communities of the Greenland-Iceland-Norwegian (GIN) Seas (Barthel \& Tendal 1993), where it contributes more than $80 \%$ to sponge community respiration (Witte $\&$ Graf 1996). It can be so might aid in controlling the water volume pumped through the sponye.

Thenea abyssorum, like many sponge species, carries heterotrophic bacteria in its tissue, and it has been suggested that these species might - at least in partlive by uptake of. DOC. As a sponge that feeds via DOC uptake is not a suitable object for particle uptake experiments, the uptake of radioactively labelled amino acids was tested prior to other experiments. The sponges, perhaps not too surprisingly, were able to take up DOC. However, with $700 \mathrm{pg}$ ind.- $\mathrm{d}^{-1}$ the uptake rates were too low to play a major role in the energy budget of the species.

Thenea muricata (Bowerbank, 1858)

Thenea muricata is the most abundant sponge species in deep fjords of western Norway. Similar to $T$. abyssorum, the species colonizes soft bottom, anchoring itself in the sediment with 1 or several spicule root tufts. Individuals reach a diameter of 6 to $8 \mathrm{~cm}$. Small individuals are mushroom-shaped with 1 central osculumi larger specimens appear more flattened with several oscula. For detailed descriptions see Sollas (1882), Babic (1916) and Steenstrup \& Tendal (1982). For the experiments, sponges of varying size up to $5 \mathrm{~cm}$ in diameter were used

\section{Sampling}

Specimens of Thenea abyssorum were sampled during 2 cruises with the RV 'Meteor' to the Norwegian 


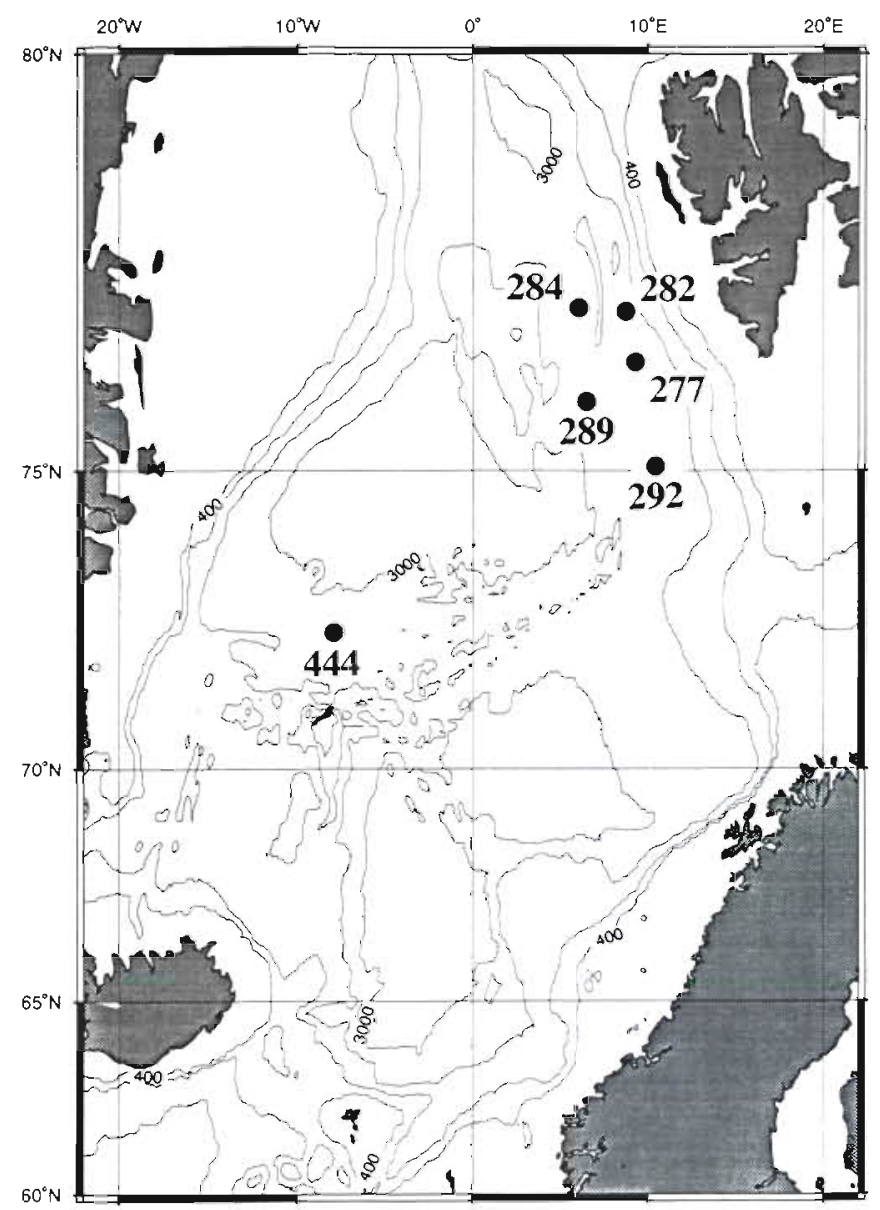

Fig. 2. Location of stations in the Norwegian-Greenland Sea. For additional station information see Table 1 Depth represented along contours at 400,1000,2000 and $3000 \mathrm{~m}$

and Greenland Sea at depths of $2000 \mathrm{~m}$ or more (Fig. 2, Table 1). The sponges were sampled with a modified box corer $(50 \times 50 \mathrm{~cm})$ that carries 4 plexiglass tubes of $19 \mathrm{~cm}$ inner diameter. The low surface water temperatures in the study area allowed sampling with only minor heating and thus made it possible to obtain living specimens that had not been subjected to rapid temperature changes: on deck, the overlying water in the box cores had a temperature of 1 to $2^{\circ} \mathrm{C}$, compared to $-0.9^{\circ} \mathrm{C}$ at the sea floor Generally, sediment cores of 20 to $25 \mathrm{~cm}$ length with fairly undisturbed surfaces were obtained, with an overlying water column of ca $20 \mathrm{~cm}$. Immediately after recovery of the gear these microcosms were removed and transferred to a specially designed cooling container, where they were maintained at in situ temperatures. Twice a week about one third of the overlying water column was removed and replaced by precooled bottom water. Following each cruise the cooling container was shipped to Kiel, where experiments could thus be carried out about 4 to 6 wk after sampling For maintenance and experiments, water from $>2000 \mathrm{~m}$ was sampled and stored during the cruises. Heat production measurements, which had also been carried out on board (Witte \& Graf 1996), were conducted before flume experiments were started in order to insure that the specimens used were healthy.

Specimens of the closely related species Thenea muricata were sampled during 2 cruises with the RV 'Hans Brattström' on 19 and 29 February 1993 at $630 \mathrm{~m}$ depth in the Korsfjord, western Norway $\left(60^{\circ} 08.8^{\prime} \mathrm{N}\right.$, $05^{\circ} 07.0^{\prime} \mathrm{E}$ ). The sponges were maintained at in situ temperatures of 5 to $6^{\circ} \mathrm{C}$ in a constant temperature room at the Dept of Fisheries and Marine Biology, University of Bergen, where flume experiments were carried out during the following days. For maintenance and experiments, filtered fjord water from $100 \mathrm{~m}$ depth was used.

\section{Flume experiments}

All flume experiments were carried out at in situ temperatures in recirculating flumes. According to Nowell \& Jumars (1987) no flume design is applicable to all problems in benthic biology. Our flumes are basically designed as outlined in Vogel (1981), with some modifications considering design criteria given in Nowell \& Jumars (1987). The channels of the 2 flumes are 3 (2) $\mathrm{m}$ long and 0.4 (0.3) $\mathrm{m}$ wide and high, i.e. length/width ratios are 7.5 and 6.7 , respectively. Water level was $15(10) \mathrm{cm}$ giving width/water depth ratios of 2.7 (3). Nowell \& Jumars suggest a minimum value of 5 for the width/depth ratio in order to reduce side wall effects. However, for the current velocities used in this study side wall effects end $7 \mathrm{~cm}$ from the side walls. As the test section was situated with $10 \mathrm{~cm}$ distance to each side wall, boundary effects as described by Nowell \& Jumars (1987) were assumed to be negligible. In addition, they themselves have used a width/depth

Table 1 Crusses, locations and depth of stations. BC: box corer. For details see Suess \& Altenbach (1992) and Pfannkuche et al. (1993)

\begin{tabular}{|lccccc|}
\hline Cruise-Leg & Stn & Latitude & Longitude & Depth $(\mathrm{m})$ & Gear \\
\hline Meteor $17-1$ & 444 & $72^{\circ} 21.1^{\prime} \mathrm{N}$ & $07^{\circ} 48.4^{\prime} \mathrm{W}$ & 2630 & $\mathrm{BC}$ \\
Meteor $21-4 / 5$ & 277 & $76^{\circ} 286^{\prime} \mathrm{N}$ & $08^{\circ} 44^{\prime} \mathrm{E}$ & 2020 & $\mathrm{BC}$ \\
Meteor $21-4 / 5$ & 282 & $76^{\circ} 51.0^{\prime} \mathrm{N}$ & $08^{\circ} 243^{\prime} \mathrm{E}$ & 2360 & $\mathrm{BC}$ \\
Meteor $21-4 / 5$ & 284 & $7^{\circ} 040^{\prime} \mathrm{N}$ & $06^{\circ} 21.8^{\prime} \mathrm{E}$ & 2150 & $\mathrm{BC}$ \\
Meteor $21-4 / 5$ & 289 & $75^{\circ} 59.5^{\prime} \mathrm{N}$ & $06^{\circ} 21.4^{\prime} \mathrm{E}$ & 2160 & $\mathrm{BC}$ \\
Meteor $21-4 / 5$ & 292 & $75^{\circ} 18.5^{\prime} \mathrm{N}$ & $09^{\circ} 46.2^{\prime} \mathrm{E}$ & 2570 & $\mathrm{BC}$ \\
\hline
\end{tabular}


ratio of 3 in experiments on flow dynamics within seagrass beds (Gambi et al. 1990).

For the particle uptake experiments, the smaller flume was used $(2 \mathrm{~m}$ long and $30 \mathrm{~cm}$ wide; for details see Ziebis 1991), which allowed the $20 \mathrm{~cm}$ tubes (microcosms) to be introduced and set level with the sediment surface inside the flume. The sponges thus stayed in their natural position half buried in the sediment and did not have to be touched or removed from the sediment. Fluorescent particles (microspheres, Duke Scientific Corporation ${ }^{(1)}$ ) with a density of $1.05 \mathrm{~g}$ $\mathrm{cm}^{-3}$ were used to study particle uptake by the sponges. As sponges are unable to distinguish between digestible and non-digestible particles (Pourbaix 1933, Kilian 1952, Willenz \& van de Vyver 1982), a protein coating was not applied. Particles of $1,2,3,6$, 10 and $16 \mu \mathrm{m}$ diameter were used. All flume experiments lasted 5 to $6 \mathrm{~h}$. At each flow speed, 2 replicate experiments were carried out with Thenea abyssorum and 3 with $T$. muricata. In the case of $T$. abyssorum, the biomass of the sponges in the flume was too low to cause considerable reduction of particle concentration in the flume water. Number and size of particles taken up by this species therefore had to be determined directly. For this purpose, 2 methods were used. (1) Histological sections of tissue samples from some of the sponges were prepared for TEM analysis in order to ensure that particles had been taken up into the sponge tissue (Witte unpubl.). (2) The remaining sponges were dissolved in nitric acid. From the mixture of sponge spicules and microspheres, the latter were separated out by means of density separation with calcium bromide (modified according to Thomsen 1991) and counted using an epifluorescence microscope. Prior to this procedure sponges were placed in glass beakers with filtered seawater to allow for cleaning of the canal system in order to exclude particles trapped in the canal system but not taken up into the tissue.

During the experiments with Thenea muricata, particle concentration in the flume water was determined every 30 min by means of a coulter counter. To account for the unavoidable 'natural loss' of particles, e.g in the recirculation tube and resulting from passive deposition of particles on the sediment surface not due to the presence and activity of sponges, an identical experiment without sponges was run for each experiment. The reference values achieved this way were then subtracted from the raw data. After the termination of each experiment, size and ash-free dry weight (AFDW) of all sponges were determined. Prior to each experiment the flume bottom was covered with a sediment layer and the flume was then filled with filtered $(10 \mu \mathrm{m})$ deep-sea water. The system was run for $2 \mathrm{~d}$ at medium flow speed $\left(\mathrm{ca} 3 \mathrm{~cm} \mathrm{~s}^{-1}\right)$, with the water being permanently aerated. After $2 \mathrm{~d}$, sediment cores and sponges were implanted and given another $3 \mathrm{~d}$ to adjust to the system. Water samples were analysed to determine the natural particle freight ( 2 to $16 \mu \mathrm{m}$ ) of the water and a microsphere suspension was prepared that would result in an equal amount of natural and artificial particles of each size class in the flume water Following these $3 \mathrm{~d}$ the aeration was stopped and the particle suspension was slowly added. Five minutes after injection the first water sample was taken. From the decreasing particle concentration the clearance rate was calculated for 30 min intervals.

For determination of flow fields around the sponges the large flume, equipped with a system for measuring current velocity with high spatial resolution (Springer 1996) that was not available in 1993, was used. An acoustic Doppler current meter (Sontek, San Diego, CA, USA) was mounted onto a movable unit that allowed positioning of the sensor with an accuracy of $0.2 \mathrm{~mm}$. Measurements of all 3 orthogonal components of the velocity vector $\left(v_{x}, v_{y}, V_{2}\right)$ were taken and, as measurements were taken $5 \mathrm{~cm}$ below the sensor, the influence of the probe itself was assumed to be negligible. The measurements of flow fields were taken around 2 dead Thenea abyssorum individuals that were placed onto a sediment layer in the flume in their natural position (see Fig. 1). The sponges had diameters of 18 and $13 \mathrm{~mm}$, and their height above the sediment was 13 and $8 \mathrm{~mm}$, respectively; they were positioned ca $100 \mathrm{~cm}$ downstream from the leading edge (rectifier grid). For the current velocities used here, the flume allows development of a boundary layer thickness of $5 \mathrm{~cm}$ over smooth surfaces. The boundary layer is fully developed about $0.9 \mathrm{~m}$ from the leading edge. The animal height/boundary layer height ratios are 0.2 and 0.37 for the 2 species respectively and thus are close to the ratio of 0.33 recommended by Nowell \& Jumars (1987). Current velocity profiles were measured at 2 free stream velocities, 1 and $5 \mathrm{~cm} \mathrm{~s}^{-1}$ Vertical profiles were taken $5 \mathrm{~cm}$ in front, directly above and $4 \mathrm{~cm}$ behind the larger of the 2 specimens. Horizontal profiles were measured $1 \mathrm{~cm}$ above the bottom (which is approximately the height of the in-and exhalent openings) with a grid resolution of $4.83 \mathrm{~mm}$. From the 3 velocity components, turbulence intensity $T I$ was calculated as

$$
T I=100 \times \frac{\sqrt{\Delta v_{x}{ }^{2}+\Delta v_{y}{ }^{2}+\Delta v_{z}{ }^{2}}}{\sqrt{v_{x}{ }^{2}+v_{y}{ }^{2}+v_{z}{ }^{2}}}
$$

(Gambi et al. 1990). Shear velocity $u^{*}$ and the roughness length $z_{0}$ were calculated from the KarmanPrandtl $\log$ profile (e.g. Middleton \& Southard 1984, Mann \& Lazier 1991). From these parameters near-bed particle dynamics can be inferred (Jumars 1993). 

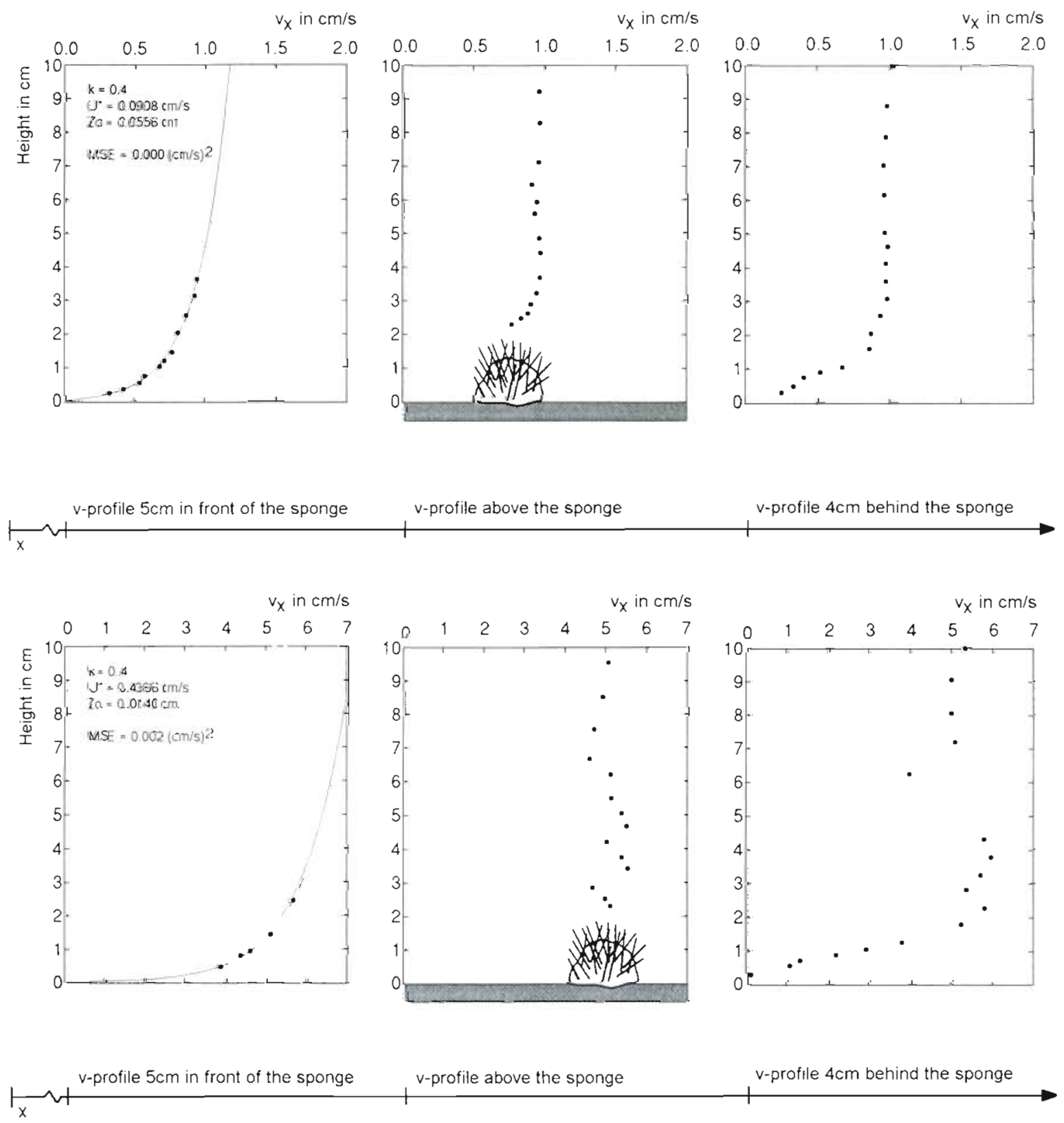

Fig. 3. Profiles of current velocity in front of, above and behınd a specımen of Thenea abyssorum at free-flow velocities of $1 \mathrm{~cm} \mathrm{~s}^{-1}$ (top) and $5 \mathrm{~cm} \mathrm{~s}^{-1}$ (bottom). Grey dots: data not used for calculation of log profiles

\section{RESULTS}

The vertical current profiles show that a well developed boundary layer (see above) existed in front of the sponges (Fig. 3). For the free-flow velocity $v=1 \mathrm{~cm} \mathrm{~s}^{-1}$ $\left(5 \mathrm{~cm} \mathrm{~s}^{-1}\right), u^{*}$ and $z_{0}$ were calculated as $u^{*}=0.09 \mathrm{~cm} \mathrm{~s}^{-1}$ $\left(0.44 \mathrm{~cm} \mathrm{~s}^{-1}\right)$ and $z_{0}=0.05 \mathrm{~cm}(0.01 \mathrm{~cm})$. Above and behind the sponges the boundary layer formation was disturbed and the current profiles had a different shape. Here, calculation of $u^{*}$ and $z_{0}$ from the log profile is not sensible. At $\mathrm{v}=1 \mathrm{~cm} \mathrm{~s}^{-1}$ the $\log$ profile seems to be shifted upwards by ca $1 \mathrm{~cm}$ Horizontal profiles (Fig. 4) show that the influence of the large sponge on hydrodynamic conditions was visible $14 \mathrm{~cm}$ downstream of and several $\mathrm{cm}$ lateral to the sponge. TI rose from $20 \%$ in front of to $160 \%$ behind the sponge, where a leeward deceleration of the flow occurs.

The data obtained on size and relative abundance of particles found in the specimens of Thenea abyssorum are summarized in Fig. 5. At both the low and higher current velocities, only microspheres 1 to $3 \mu \mathrm{m}$ in diameter were found inside the sponges. None of the 
a)

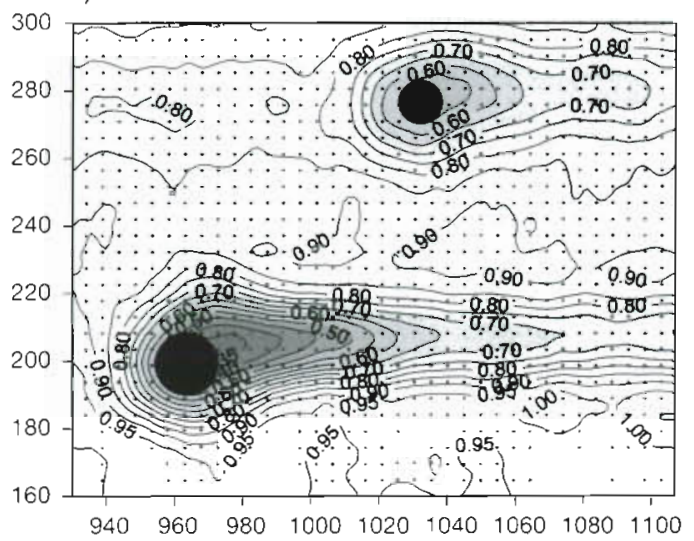

c)

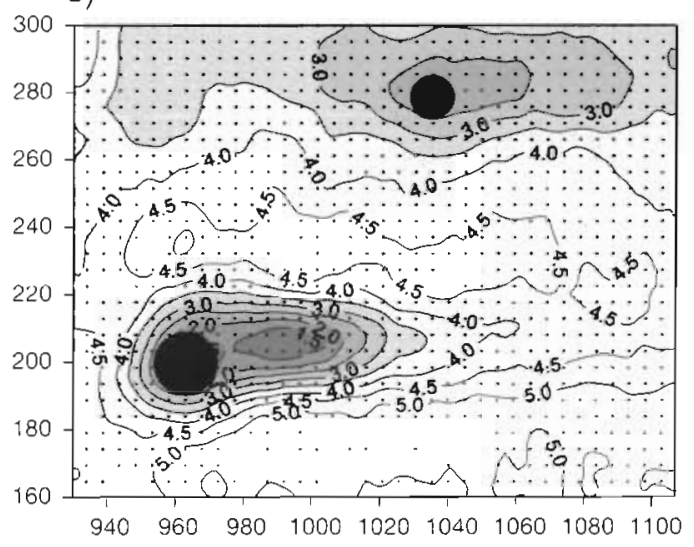

b)
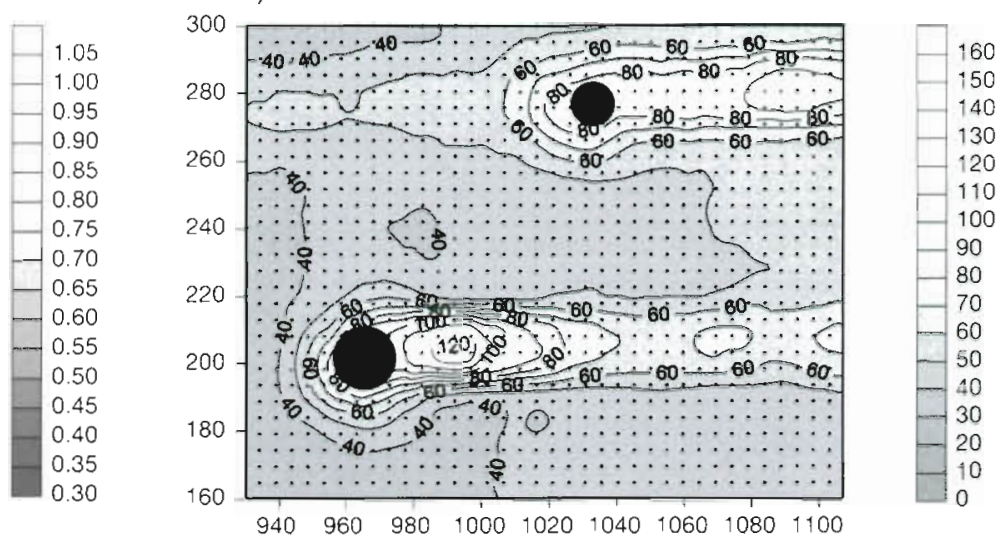

d)

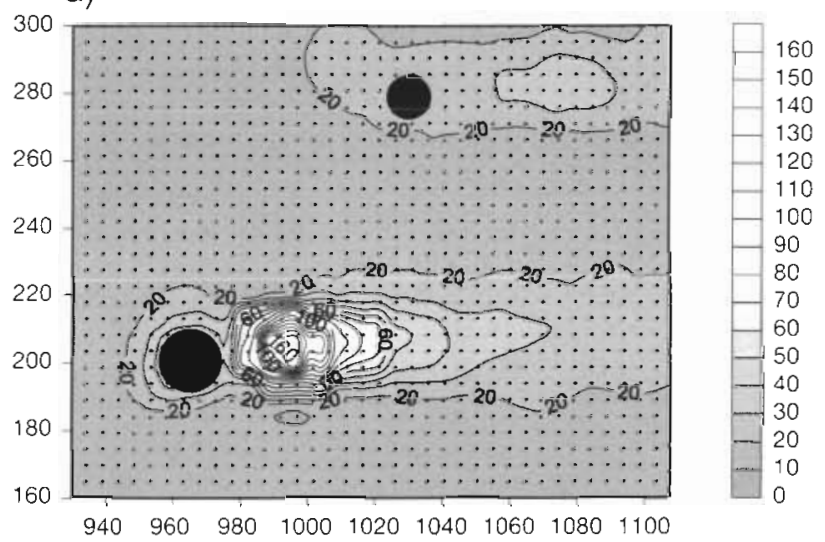

Fig. 4. Current velocity $(a, c)$ and turbulence intensity $(b, d)$ field around specimens of Thenea abyssorum at $1 \mathrm{~cm}$ height above bottom. $(a, b)$ Free-flow velocity $v=1 \mathrm{~cm} \mathrm{~s}^{-1}$; $(c, d)$ free-flow velocity $v=5 \mathrm{~cm} \mathrm{~s}^{-1} x$-axis: distance downstream from collimator $\{$ mm\}; $y$-axis: position between the sides of the canal $(\mathrm{mm})$. Small dots mark points of current measurements. Black circles symbolize sponge specimens

specimens contained larger particles. The concentration of particles in the flume water at the beginning of the experiment was fairly even, with approximately 2000 particles $\mathrm{ml}^{-1}$ for all 3 sizes $(1,2$ and $3 \mu \mathrm{m})$. Particle uptake, however, was selective: $40 \%$ of the particles found inside the sponges were small $(1 \mu \mathrm{m})$, ca $30 \%$ were $2 \mu \mathrm{m}$ and only 15 to $20 \%$ were $3 \mu \mathrm{m}$. Varying current speeds, on the other hand, did not influence the size spectrum taken up. As $T$ abyssorum is a very small species and only a limited number of living specimens was available, the sponge biomass in the flume was not sufficient to cause a significant decrease in particle concentration in the flume water Additional experiments were carried out with $T$. muricata from Korsfjord, western Norway. Again, experiments were carried out at 2 different current speeds. The particle concentrations during the experiments (calculated as the difference between the main experiment with sponges and an identical experiment without sponges) are shown in Figs. 6 \& 7 As shown in Fig. 6 , at a low current speed the concentration of small particles continually decreased, whereas the coarser fraction $(10$ and $16 \mu \mathrm{m})$ was not affected. During the second set of experiments with higher current speed (Fig. 7) this decrease was much faster. The concentration of the 2 and $3 \mu \mathrm{m}$ fractions sank within $4 \mathrm{~h}$ to ca 300 particles $\mathrm{ml}^{-1}$ and then stayed more or less constant. Whether this constant particle concentration resulted from an equilibrium between removal and addition cannot be decided. The $6 \mu \mathrm{m}$ particles decreased constantly throughout the experiment and the $10 \mu \mathrm{m}$ particles, unaffected at low flow speed, decreased rapidly after $3.5 \mathrm{~h}$.

From the decrease in particle concentration between $t=60 \mathrm{~min}$ and $t=240 \mathrm{~min}$. mean clearance rates were calculated for the 2 to $6 \mu \mathrm{m}$ size fractions and both flow speeds. The clearance rate (a theoretical value describing the volume of water per unit time that an organism filters free of particles, given in $1 \mathrm{~h}^{-1} \mathrm{~g}^{-1}$ AFDW) ranged between 5 and $9 \mathrm{l} \mathrm{h}^{-1} \mathrm{~g}^{-1}$ AFDW or 17 and $30 \mathrm{ml} \mathrm{min}^{-1}$ $\mathrm{g}^{-1}$ DW (AFDW is ca $20 \%$ of DW for Therea muricata, Witte unpubl.). It was higher for smaller particles and. 


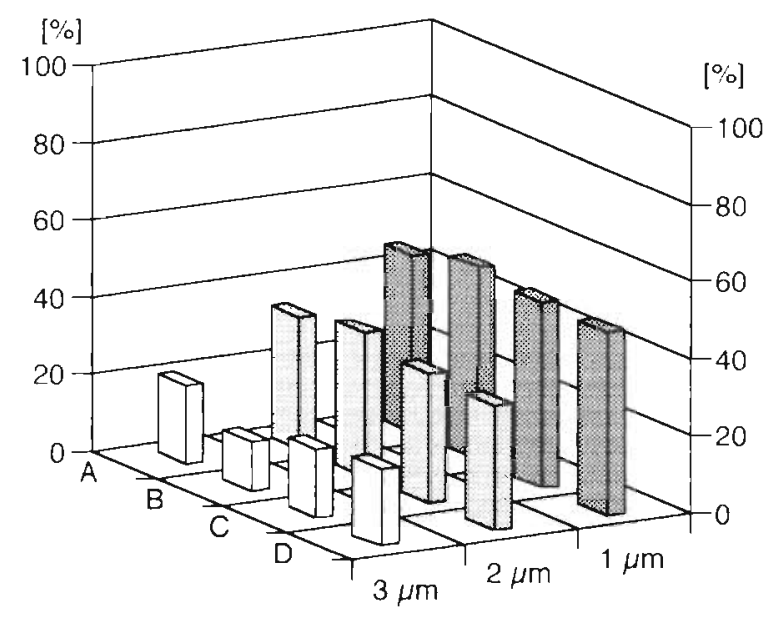

particle size

Fig. 5. Thenea abyssorum. Percentage of particles of different sizes ingested by sponges during 4 experiments at 2 current speeds. (A, B) $1.5 \mathrm{~cm} \mathrm{~s}^{-1},(C, D) 5 \mathrm{~cm} \mathrm{~s}^{-1}$. (Larger particles were

not ingested and are thus not shown in the diagram)

increased with increasing current velocity. In addition to the mean clearance rate, clearance rates were calculated for 30 min intervals throughout the experiment to monitor possible variations (Fig. 8). As can be seen, the clearance rate was not constant throughout the experiment: at low current speed it increased for 3 and $6 \mu \mathrm{m}$ particles until the end of the experiment whereas it increased then decreased again for the $2 \mu \mathrm{m}$ size fraction. At a higher currenl speed it decreased after 3 to $4 \mathrm{~h}$ for both 2 and $3 \mu \mathrm{m}$ particles; only for $6 \mu \mathrm{m}$ particles did it remain high until the end of the experiment.

\section{DISCUSSION}

As benthic organisms, sponges live in the current gradient of the benthic boundary layer However, with the exception of in situ studies conducted by Reiswig (1971a, 1975) with 3 marine demosponge species and by Frost $(1978,1980)$ with the freshwater sponge Spongilla lacustris, particle uptake of sponges has mainly been studied in laboratory experiments either under still-water conditions or in uncontrolled turbulent conditions created to keep the particles in suspension This flume study was an attempt to address the phenomenon of sponge particle uptake under naturelike boundary layer conditions. Flow conditions in boundary layers can be divided into laminar and turbulent flow, characterized by Reynolds numbers $(R e=$ $v \times l / v$, where $v$ is current velocity, $l$ is the characteristic length, and $v$ is the kinematic viscosity of a fluid). In our flume experiments we attempted to create smooth turbulent flow conditions $(\operatorname{Re}=40$ to 200000; Vogel
1981) that frequently occur in the field. For $v=1 \mathrm{~cm} \mathrm{~s}^{-1}$ $\left(v=5 \mathrm{~cm} \mathrm{~s}^{-1}\right.$ ) Re was calculated at 5000 (25000) (using $\mathrm{l}=$ distance from sponge to leading edge) and thus falls into the range defined above. Turbulence intensity in front of the sponges was ca $20 \%$ and thus somewhat higher than field data of $T I=5$ to $10 \%$ reported by Middleton \& Southard (1984). However, it is not indicated in that study whether all 3 velocity components were chosen to calculate $T I$ as in the method described by Gambi et al. (1990). Both Re and II thus confirm the existence of nature-like conditions. Note that turbulence intensity is used as a means to compare flow
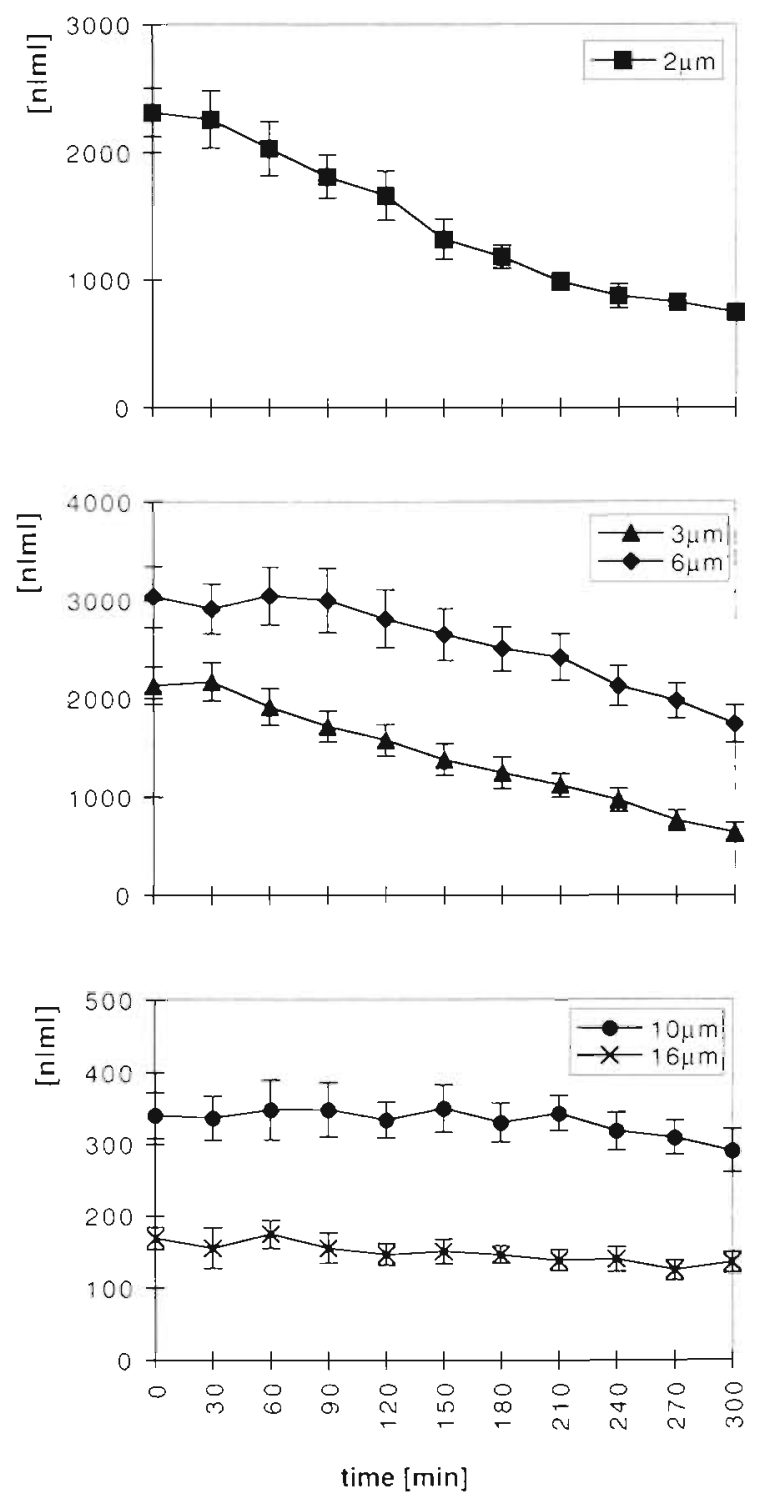

Fig. 6. Particle concentration (mean $\pm \mathrm{SD}$ ) during 5 h flume experiments (calculated as the difference between the main experiment with sponges and an identical reference experiment without sponges) with Thenea muricata at $v=1.5 \mathrm{~cm} \mathrm{~s}^{-1}$. Sponge biomass $4.2 \mathrm{~g}$ AFDW 

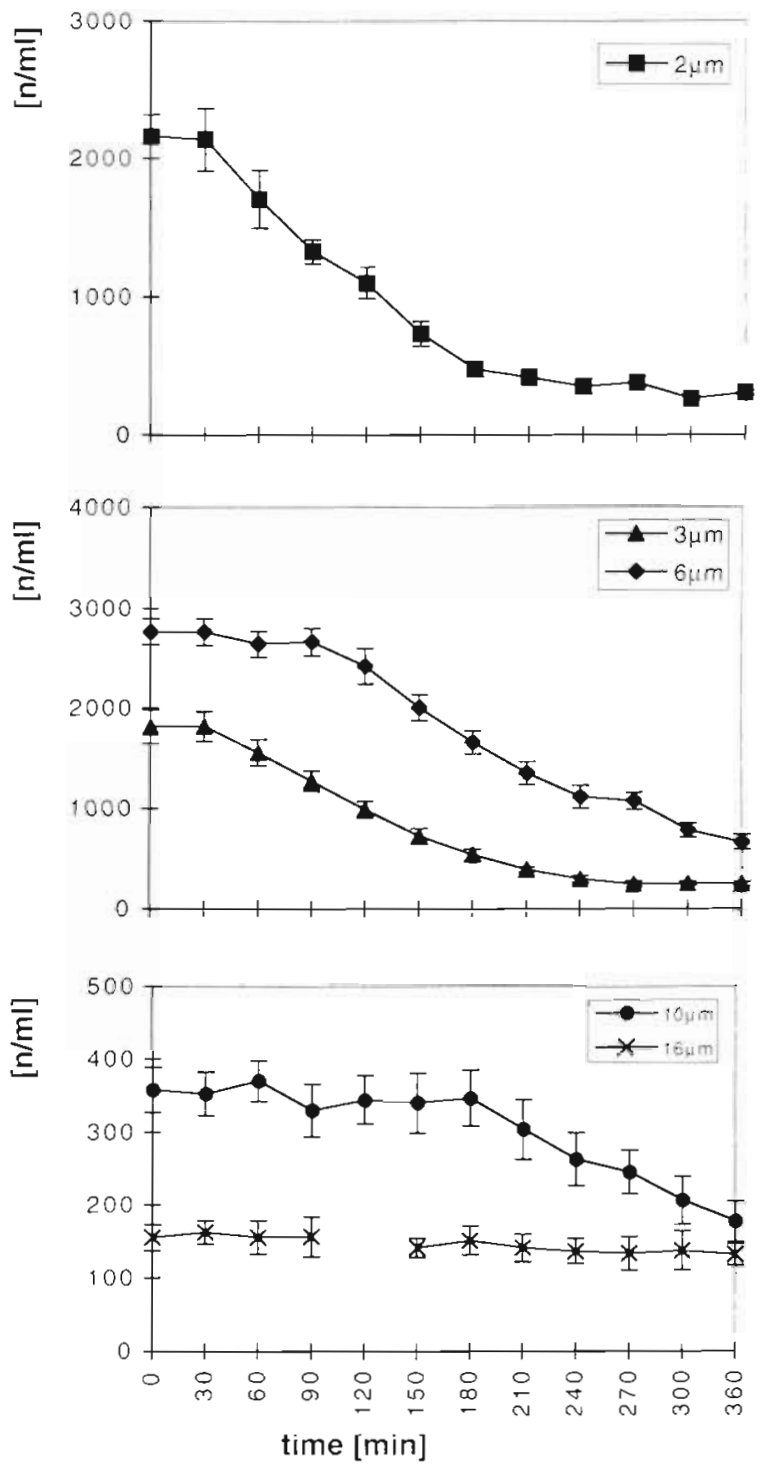

Fig. 7 Particle concentration (mean $\pm \mathrm{SD}$ ) during 6 h flume experiments (calculated as the difference between the main experiment with sponges and an identical reference experiment without sponges) with Thenea muricata at $\mathrm{v}=5 \mathrm{~cm} \mathrm{~s}^{-1}$ Sponge biomass $=4.6 \mathrm{~g}$ AFDW

regime at varying free-flow velocities. High values of $T I$ thus do not necessarily mirror strong forces, as the standard deviation from flow velocity can be relatively high, especially at low flows. Thus the high turbulence intensity at the leeward side of the sponges, although indicating the presence of wake perturbations, represents an area of low energy.

\section{Particle capture}

Thenea abyssorum took up particles of up to $3 \mu \mathrm{m}$, whereas $T$ muricata took up particles of up to $6 \mu \mathrm{m}$ and in the second set of experiments up to $10 \mu \mathrm{m}$ This is in accordance with qualitative results of Göbel (1993), who studied particle uptake in 8 shallow-water sponges of different taxa that all accepted particles 0.15 to $6 \mu \mathrm{m}$ in diameter. Only 2 species, the calcareous sponge Leucosolenia $\mathrm{sp}$. and the freshwater sponge Spongilla lacustris, were able to cope with larger particles of 9.6 and $21 \mu \mathrm{m}$, respectively. For particles $<63 \mu \mathrm{m}$, however, mean transport velocity does not differ significantly from mean current speed (Eisma 1993). Particles are assumed to behave like water and follow the streamlines around obstacles. This raises the question of how they become available to the sponges. Several processes seem likely (Fig 9): For irregular structures like specimens of $T$ abyssorum it is difficult to determine the surrounding 3D flow field without flow visualization. This has, however, been done for an animal tube mimic (Eckman \& Nowell 1984): a down-
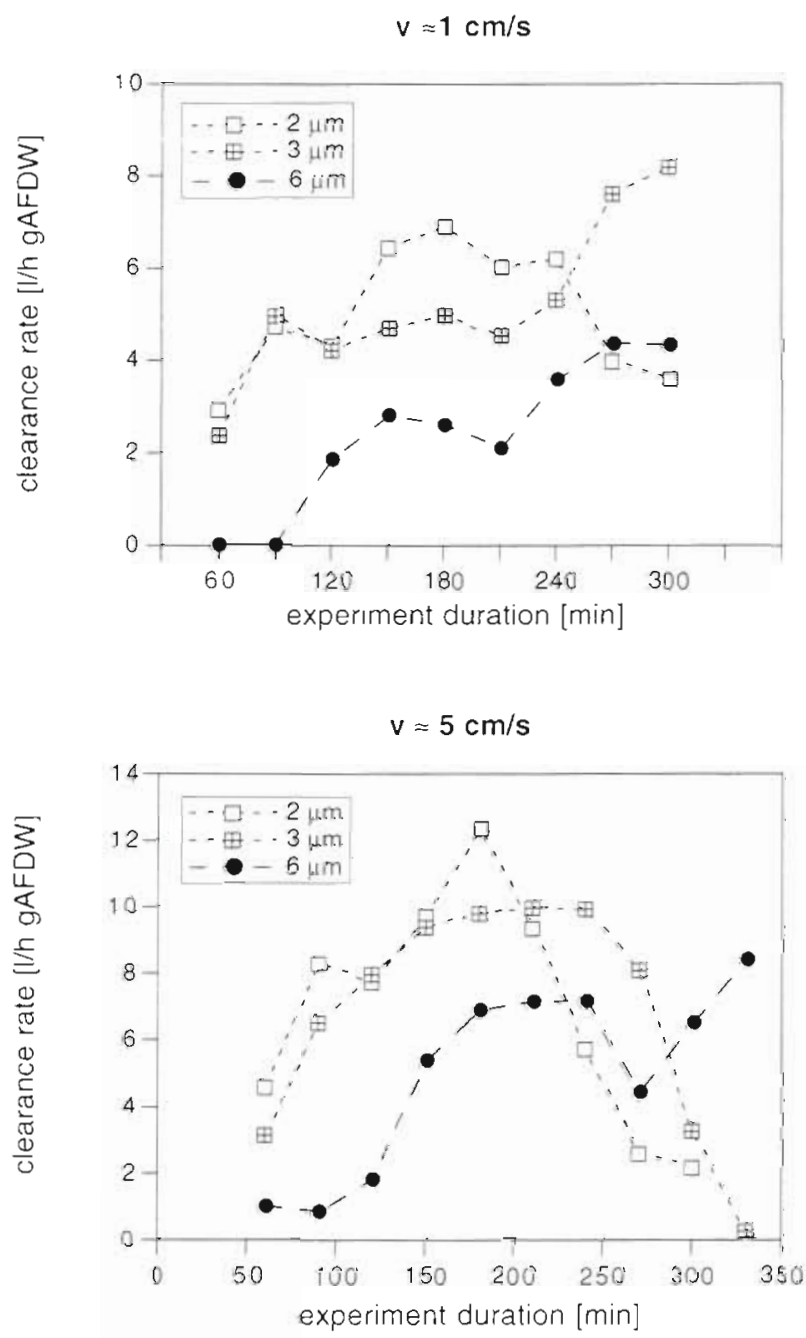

Fig. 8. Variation in clearance rates of Thenea muricata for different particle sizes during experiments with $v=1.5 \mathrm{~cm} \mathrm{~s}^{-1}$ (above) and $\mathrm{v}=5 \mathrm{~cm} \mathrm{~s}^{-1}$ (below) 




Fig. 9. Schematic drawing of possible particle capture modes in Thenea abyssorum. (1) Breakage of aggregates into smaller particles that decelerate and thus become available to the sponge; (2) intrusion of small particles into the sponge's spicule 'fur'; (3) uplift of small particles due to increased turbulence; (4) downward transport of particles due to vortex at the leeward side of the sponge

ward vortex developed downstream from the tube and the flow velocity strongly decreased, facilitating the deposition of particles. As the turbulence intensity field around $T$ abyssorum (Fig. 4) also indicated strong current deceleration behind the sponge, it is assumed that a similar vortex developed. If this holds true, the flow deceleration and downward vortex on the leeward side might facilitate the ingestion of particles. As can be seen in Fig. 4, the deceleration of flow behind the sponges for both current speeds is much stronger behind the larger specimen, which would thus profit more from this phenomenon than smaller ones. In these specimens, the leeward side might be the main area of particle uptake. In areas with a rather stable flow regime or with a predominant flow direction it could then be advantageous to orient correspondingly. Unfortunately, no observations on the orientation of sponge ostia with repect to flow exist. Carey (1983), on the other hand, investigated the polychaete Lanice conchilega and demonstrated resuspension in upward spiral vortex filaments downstream from the tube. Both scenarios, although contrasting, provide the sponge with otherwise non-available particles and might thus increase food supply for the animal at the leeward side. The high turbulence intensity behind the larger individuals can also cause an opposite phenomenon: at high $T I$ and low flow, low excess density particles can experience uplift (Jumars 1993). Small organic parti- cles, created e.g. by the disruption of aggregates, might thus be transported out of immediate reach of suspension-feeding benthic organisms.

The sponges might also profit from the permeability of their spicule 'fur': the intrusion of $10 \mu \mathrm{m}$ particles into permeable sediments, driven by pressure gradients generated when boundary layer flows interact with topography, has recently been demonstrated (Hüttel et al. 1996). Small particles could also be decelerated and thus become available in the needle mesh around the sponge where flow is reduced. The needles probably also cause the breakage of larger aggregates. This breakage of aggregates possibly is of great importance: up to $65 \%$ of the bacterial population in near-bottom deep waters lives in association with particles. Free-living bacteria that match the preferred sponge food size are correspondingly scarce (Thomsen \& Graf 1994) and aggregate breakage could thus provide the sponges with food of high nutritional value. It must, however, be kept in mind that sponges are active suspension feeders able to create water circulation that by itself might supply a sufficient amount of food particles. To separate the importance of the varying processes and weigh the role of active pumping in deep-sea sponge feeding, a detailed survey of flow patterns around actively pumping specimens would be necessary.

\section{Selection of particles}

If particles $<63 \mu \mathrm{m}$ become available for deep-sea sponges, a filter mechanism obviously prevents the ingestion of particles $>6-10 \mu \mathrm{m}$. Göbel (1993) gives a compilation of ostial diameters determined by various authors, and states that-although they function as a filter - the ostia, which have a diameter of 20 to $70 \mu \mathrm{m}$, are far too large to filter out the smaller particles. Göbel suggests that the limit is set by the size of choanocytes, endopinacocytes and archaeocytes as all particles have to be ingested by the one or the other cell type. This is, however, not fully convincing as freshwater sponges are able to take up much larger particles than marine sponges without having correspondingly larger archaeocytes. In addition, it is difficult to envisage a passive filtering mechanism in which ostial diameter or mean cell size mediates the preferential uptake of certain size classes within the acceptable size range. Hydrodynamical sorting of particles in the benthic boundary layer is a well known phenome- 
non (e.g. Muschenheim 1987a, b), but as mean transport velocity differs significantly from mean current speed only for particles $>63 \mu \mathrm{m}$ (Eisma 1993), the selection effects observed here cannot be explained as an effect of hydrodynamical sorting either Is the preferential uptake of smaller particles in Thenea then created by an active selection process? A striking capability of selective particle retention was described by Wilkinson et al. (1984), who found that sponges were able to descriminate between bacteria from ambient waters - which were retained - and symbiotic bacteria which were not retained. Our experiments with Thenea muricata support this hypothesis: in both experiments the concentration of smallest ( 2 and $3 \mu \mathrm{m}$ ) particles declined rapidiy, as did the $6 \mu \mathrm{m}$ fraction $2 \mathrm{~h}$ later. This could indicate that it is the decline of small (i.e. preferred?) particles that leads to the uptake of the larger size fraction. We have, however, stated above that particles can be taken up via 2 pathways. The delayed uptake of 6 m particles might thus reflect the fact that pathway 2 needs a 'reaction time' until a sufficient number of archaeocytes has gathered. Also, cells might reach a saturation point as reported by Willenz \& Rasmont (1979) for choanocytes of Ephydatia fluviatilis. However, during the second set of experiments the $10 \mu \mathrm{m}$ particles started to decrease $3 \mathrm{~h}$ after the beginning of the experiment. As 6 and $10 \mu \mathrm{m}$ particles are ingested via the same pathway, selection here must have taken place independently from the ingestion mechanism. In addition, the $10 \mu \mathrm{m}$ particles were not affected at low flow speed when smaller particles decreased far more slowly. This supports the hypothesis that the uptake of larger particles is conmected to the disappearance of smaller food items. The uptake of particles of a certain size class would thus depend on the availability of certain particles rather than on current velocity, as described for other suspension feeding taxa (e.g. Okamura 1990).

\section{Clearance rates}

Clearance rates were detcrmined from $t=60 \mathrm{~min}$ instead of $t=0$ min as the experiments showed a time lag between the start of the experiment and the beginning of a decrease in particle loads. Pumping activity is not necessarily constant in sponges: long-term studies of pumping activities in 3 tropical demosponges (Reiswig $1971 \mathrm{~b}$ ) revealed that one species maintained a constant level of activity, one species displayed high pumping activity for long periods interrupted by short periods of complete cessation, and one species maintained an alternating active-inactive cycle over a long time span. On the other hand, active pumping without filtering has a]so been described by Wilkinson et al. (1984). A possi- ble explanation could be the existence of bypasses connecting the inhalant and exhalant canal system directly, as described by Bavestrello et al. (1995). From our experiments it cannot be determined whether the sponges were inactive or instead pumping but not filtering during the initial period. As these periods have been excluded from calculations, the mean clearance rates of 17 to $30 \mathrm{ml} \mathrm{min} \mathrm{m}^{-1} \mathrm{~g}^{-1}$ DW obtained have to be regarded as maximum values. They are in the range of filtration. rates estimated for Haliclona urceolus and Halichondria panicea (Riisgărd et al. 1993, Thomassen \& Rijsgård 1995). As can be seen in Fig. 8, clearance rates varied considerably both between different-sized particles and over the course of the experiment, indicating that the sizo classes are retained with varying efficiency. This is in agreement with findings of Reiswig (1971a), who found retention rates to vary considerably between different food items, which underlines the sponges' ability to actively select parlicles

\section{Deposition of particles}

Most sponges are suspension feeders, but the fate of indigestable food items has long remained unknown. Both Kilian (1952) and Weissenfels (1976), during their studies of freshwater sponges, noted the ejection of pellets. However, they only recorded single observations. Wolfrath \& Barthel (1989) studied pellet production in the shallow-water sponge Halichondria panicea Pallas. Laboratory feeding experiments with both latex beads and algal cultures demonstrated the production of oval to rounded pellets of 15 to $50 \mu \mathrm{m}$ diameter. The pellets were always covered by a thin membrane. This cover proved to be very labile but the pellets did not fall apart when it was destroyed. Göbel (1993) continued this investigation with another 5 marine demosponge species and demonstrated that all species studied produced similar pellets of 30 to $100 \mu \mathrm{m}$ length. Single, uncoated particles never were ejected. As Göbel studied representatives of various demosponge groups and found all of them to produce pellets, and as histological preparations of the species studied here (Witte 1996) contained cysts filled with food remains, it is assumed that these pellets can be regarded as typical for suspension-feeding sponges. This implies that the deep-sea species studied here ingest small particles up to $6 \mu \mathrm{m}$ in diameter which after digestion are ejected as pellets up to $50-100 \mu \mathrm{m}$ in size and thus become available to deposit feeding organisms. The filtration activity of these sponges thus mediates the deposition of very fine grained material. Such coupling has, for example, been observed by Amouroux et al. (1990) and Ziebis (1991) in microcosm experiments with shallow-water bivalves and polychaetes. 
Table 2. Biodeposition mediated by the deep-sea sponge community of the GIN Seas

\begin{tabular}{|cccc|}
\hline Stn & $\begin{array}{c}\text { Depth } \\
(\mathrm{m})\end{array}$ & $\begin{array}{c}\text { Sponge biomass } \\
\left(\mathrm{mg} \mathrm{AFDW} \mathrm{m}^{-2}\right)\end{array}$ & $\begin{array}{r}\text { Biodeposition } \\
\left(\mathrm{mg} \mathrm{C} \mathrm{m}^{-2} \mathrm{~d}^{-1}\right)\end{array}$ \\
\hline 277 & 2020 & 664 & 0.97 \\
289 & 2160 & 1524 & 2.24 \\
292 & 2570 & 240 & 0.59 \\
444 & 2630 & 536 & 0.79 \\
\hline
\end{tabular}

\section{Biodeposition rate of the poriferan community from the deep GIN Seas}

As outlined above, suspension feeders can mediate the deposition of laterally transported particles by their feeding activity. In addition, being passive obstacles for bottom currents, they increase sediment roughness and can thus-depending on form, size and frequency - create sediment deposition or erosion (e.g. Eckman et al. 1981, Luckenbach 1986, Vogel 1994), although a consistent functional grouping of organisms as stabilizers or destabilizers, or as decreasers or enhancers of erosion, respectively, is not possible (Jumars \& Nowell 1984). In this study, active and passive deposition of particles could not be separated. Nevertheless, a bulk biodeposition rate could roughly be calculated from the volume of particles extracted from the water column. Biodeposition amounted to $6.7 \mathrm{~mm}^{3} \mathrm{~d}^{-1} \mathrm{~g}^{-1}$ AFDW (low current speed) and $9.3 \mathrm{~mm}^{3} \mathrm{~d}^{-1} \mathrm{~g}^{-1}$ AFDW (high current speed) or 7.3 and $10.2 \mathrm{mg} \mathrm{d}^{-1} \mathrm{~g}^{-1}$ AFDW, respectively, assuming a density of $1.05 \mathrm{~g} \mathrm{~cm}^{-3}$. As particles smaller than $2 \mu \mathrm{m}$ are not included, this has to be considered a conservative estimate. Filtering activity was assumed to be constant. This is in accordance with the work of Reiswig (1971b), who monitored excurrent velocity in the oscula of 3 demosponge species and found it to be constant for months in 2 of the species. The third species showed a clear diurnal pumping rhythm, which, however, is not to be expected in deep-sea species. The combination of biodeposition rates with biomass data for the Norwegian and Greenland Seas allows a rough estimate for sponge community biodeposition, which is given in Table 2. Biodeposition rate for the sponge community of the deep Greenland and Norwegian Seas ranges between 0.5 and $2.0 \mathrm{mg} \mathrm{C} \mathrm{m} \mathrm{Cd}^{-1}$. If biomass is taken into account, this is comparable to shallow-water benthos of other taxa, e.g. $0.02 \mathrm{mg} \mathrm{C} \mathrm{g}^{-1}$ wet wt $\mathrm{d}^{-1}$ for the antarctic bivalve Laternula elliptica (Ahn 1993) compared to $0.03 \mathrm{mg} \mathrm{C} \mathrm{g}^{-1}$ wet wt $\mathrm{d}^{-1}$ for Thenea muricata Thomsen et al. (1995) give a biodeposition rate of $25 \mathrm{mg} \mathrm{C} \mathrm{m} \mathrm{C}^{-1}$ for the entire benthic community (ca 1000 ind $\mathrm{m}^{-2}$ ) in an interface feeder field at $1400 \mathrm{~m}$ depth on the Barents Sea continental slope. A comparison with sedimentation rates from the GIN Seas (annual mean: 5 to $6 \mathrm{mg} \mathrm{C} \mathrm{m} \mathrm{m}^{-2} \mathrm{~d}^{-1}$; maximum flux: 20 to $30 \mathrm{mg} \mathrm{C} \mathrm{m}^{-2} \mathrm{~d}^{-1}$; von Bodungen et al. 1995) shows that the poriferan community possibly adds up to $10 \%$ to vertical particle flux by the deposition of fine, laterally transported material.

Acknowledgements. Thanks are due to the masters and crews of RV 'Meteor' and RV 'Hans Brattstrom' for their assistance during sampling, to $W$. Queisser and J. Nittikowski for technical assistance and to $G$. Unsöld for valuable discussions. The manuscript benefited from the thorough work of 3 anonymous reviewers. This is a CEOMAR publication and publication no. 309 of Sonderforschungsbereich 313, University of Kiel.

\section{LITERATURE CITED}

Ahn IY (1993) Enhanced particle flux through the biodeposition by the Antarctic suspension-feeding bivalve Laternula elliptica in Manan Cove, King George Island. J Exp Mar Biol Ecol 171:75-90

Amouroux JM, Amouroux J, Bastide J, Cahet G (1990) Interrelations in a microcosm with a suspension-feeder and a deposit-feeder. I. Experimental study. Oceanol Acta 13(1): $61-68$

Babic K (1916) Zur Kenntnis der Theneen. In: Spengel JW (ed) Zoologische Jahrbücher Fischer Verlag, Jena, p $398-408$

Bacon MP, van der Loeff MR (1989) Removal of thorium-234 by scavenging in the bottom nepheloid layer of the ocean. Earth Planet Sci Lett 92:157-164

Barthel D, Tendal OS (1993) The sponge association of the abyssal Norwegian Greenland Sea: species composition, substrate relationships and distrubution. Sarsia 78:83-96

Bavestrello G, Burlando B, Sarà M (1995) Corrosion cast reconstruction of the three-dimensional architecture of demosponge canal systems. In: Lanzavecchia $R$, Valvassori $\mathrm{R}$ (eds) Body cavities: function and phylogeny. Mucchi, Modena, p 93-110

Carey DA (1983) Particle resuspension in the benthic boundary layer induced by flow around polychaete tubes. Can J Fish Aquat Sci 40(Suppl 1):301-308

Eckman JE, Nowell ARM (1984) Boundary skin friction and sediment transport about an animal-tube mimic. Sedimentology 31:851-862

Eckman JE, Nowell AR, Jumars PA (1981) Sediment destabilisation by animal tubes. J Mar Res 39:361-374

Eisma D (1993) Suspended matter in aquatic environments Springer-Verlag, Berlın

Frost TM (1978) In situ measurements of clearance rates for the freshwater sponge Spongilla lacustris. Limnol Oceanogr 23:1034-1039

Frost TM (1980) Clearance rate determinations for the freshwater sponge Spongilla lacustris. Effect of temperature, particle type and concentration, and sponge size. Arch Hydrobiol 90:330-356

Gage JD, Tyler PA (1991) Deep-sea biology. A natural history of organisms at the deep-sea floor. Cambridge Unuversity Press, Cambridge

Gambi MC, Nowell ARM, Jumars PA (1990) Flume observations on flow dynamics in Zostera marina (eelgrass) beds. Mar Ecol Prog Ser 61:159-169 
Gobel Y (1993) Gibt es Unterschiede in den Größenspektren der von verschiedenen Schwammarten aufgenommenen Partikel? MSc thesis, University of Kiel

Graf $G$, Rosenberg $R$ (in press) Bioresuspension and biodeposition: a review. J Mar Sci

Huttel M, Ziebis W, Forster S (1996) Flow-induced uptake of particulate matter in permeable sediments. Limnol Oceanogr 41(2):309-322

Jumars PA (1993) Concepts in biological oceanography Oxford University Press, Oxford

Jumars PA, Nowell ARM (1984) Effects of benthos on sediment transport: difficulties with functional grouping. Cont Shelf Res 3(2):115-130

Kilian EF (1952) Wasserströmung und Nahrungsaufnahme beim Susswasserschwamm Ephydatia fluviatılis. Zeitschr vergl Physiol 34:407-447

Luckenbach MW (1986) Sediment stability around animal tubes: the roles of hydrodynamic processes and biotic activity. Limnol Oceanogr 31(4):779-787

Mann KH, Lazier JRN (1991) Dynamics of marine ecosystems Biological-physical interactions in the ocean. Blackwell Scientific Publications, Boston

Middleton GV, Southard JB (1984) Mechanics of sediment movement. S.E.P.M. short course 3 SEPM, Providence, RI

Monniot C, Monniot F (1978) Recent work on the deep-sea tunicates. Oceanogr Mar Biol Annu Rev 16:181-228

Muschenheim DK (1987a) The role of hydrodynamical sorting of sestom in the nutrition of a benthic suspension feeder, Spio setosa (Polychaeta: Spionidae). Biol Oceanogr 4(3): 265-288

Muschenheim DK (1987b) The dynamics of near-bed seston flux and suspension-feeding benthos. J Mar Res 45(2): $473-498$

Nowell ARM, Jumars PA (1987) Flumes: theoretical and experimental considerations for simulation of benthic environments. Oceanogr Mar Biol Annu Rev 25:91-112

Okamura B (1990) Particle size, flow velocty, and suspensionfeeding by the erect bryozoans Bugula neritina and $B$. stolonifera. Mar. Biol 105:33-38

Paul AZ, Menzies RJ (1974) Benthic ecology of the high arctic deep sea, Mar Biol 27:251-262

Pfannkuche $O$, Duinker $C J$, Graf $G$, Henrich $R$, Thiel $H$, Zeitzschel B (1.993) Nordatlantik 92, Reise Nr. 21, 16. März-31. August 1992. Meteor-reports 93-4, University of Hamburg

Pourbaix N (1933) Étude histochimique des substances de réserve au cours de la réproduction asexuée. Ann Soc Roy Zool Belg 65:41-58

Reid RGB, Reid AM (1974) The carnivorous habit of members of the septibranch genus Cuspidaria (Mollusca: Bivalvia). Sarsia 56:47-56

Reiswig HM (1971a) Particle feeding in natural populations of three marine demosponges. Biol Bull (Woods Hole) 141: $568-591$

Reiswig HM (1971b) In situ pumping activities of tropıcal Demospongiae. Mar Biol 9:38-50

Reiswig HM (1975) Bacteria as food for temperate-water marine demosponges. Can J Zool 53:582-589

Riisgárd HU, Thomassen S, Jakobsson H, Weeks JM. Larson PS (1993) Suspension feeding in marine sponges Halichondria panicea and Haliciona urceolus: effects of temperature on filtration rate and energy cost of pumping. Mar Ecol Prog Ser 96:177-188

Sollas WJ (1882) The Sponge-fauna of Norway; a report on the Rev. A. M. Norman's collection of sponges from the

This article was submitted to the editor
Norwegian coast. Ann Mag Nat Hist (5) IX:426-453

Springer B (1996) Modifikationen des bodennahen Strömungsregimes und die Deposition von suspendiertem Material durch Makrofauna. PhD thesis, Kiel University

Steenstrup E, Tendal OS (1982) The genus Thenea (Porifera,

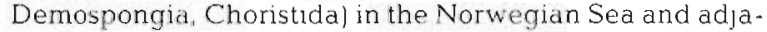
cent waters; an annotated key. Sarsia $67: 259-268$

Suess E, Altenbach V (1992) Europäisches Nordmeer, Reise Nr. 17, 15. Juli-29. August 1991. Meteor-reports 92-3, University of Hamburg

Thomassen S, Riisgärd HU (1995) Growth and energetics of the sponge Halichondria panicea. Mar Ecol Prog Ser 128: $239-246$

Thomsen L (1991) Treatment and splitting of samples for bacteria and meiofauna biomass determinations by means of a semi-automatic image analysis system. Mar Ecol Prog Ser 71:301-306

Thomsen L. Graf G (1994) Boundary layer characteristics of the continental margin of the western Barents Sea. Oceanol Acta 17(6):597-607

Thomsen L, Graf G, von Juterzenka K, Witte U (1995) An in situ experiment to investigate the depletion of seston above an interface feeder field on the continental slope of the western Barents Sea. Mar Ecol Prog Ser 123:295-300

Vacelet J, Boury-Esnault N (1995) Carnivorous sponges. Nature 373:333-335

Vogel S (1981) Life in moving fluids. The physical biology of flow. Princeton University Press, Oxford

Vogel S (1994) Life in moving fluids. The physical biology of flow, 2nd edn. Princeton University Press, Princeton

von Bodungen $B$, Antia $A$, Bauerfeind $E_{1}$ Haupt $O$, Koeve W, Peeken I, Peinert R, Reitmeier S, Thomsen C, Voss $M$, Wunsch M, Zeller U, Zeitschel B (1995) Pelagic processes and vertical flux of particles: an overview over a long term comparative study in the Norwegian Sea and Greenland Sea. Geol Rundsch 84:11-27

Weissenfels $N$ (1976) Bau und Funktion des Süßwasserschwammes Ephydatia fluviatilis L. (Porifera). III. Nahrungsaufnahme, Verdauung und Defäkation. Zoomorphology 85:73-88

Wilkinson CR, Garrone R, Vacelet J (1984) Marine sponges discriminate between food bacteria and bacterial symbionts: electron microscopy, autoradiography and in situ evidence. Proc R Soc Lond 220:519-528

Willenz P, Rasmont R (1979) Mise au point d'une technique de measure de l'activité de filtraation de jeune éponges cultivées in vitro. In: Lévi C. Boury-Esnault $\mathrm{N}$ (eds) Biologie des Spongiaires. Collog Int CCNRS, Paris, p 343-351

Willenz P, van de Vyver G (1982) Endocytosis of latex beads by the exopinacoderm in the fresh water sponge Ephydatia fluviatilis an in vitro and $n$ situ study in SEM and TEM. J Ultrastruct Res 79:294-306

Witte U (1996) Seasonal reproduction in deep-sea spongestriggered by vertical particle flux? Mar Biol 124:571-581

Witte U, Graf G (1996) Metabolism of deep-sea sponges in the Greenland-Norwegian Sea. J Exp Mar Biol Ecol 223-235

Wolfrath B, Barthel D (1989) Production of faecal pellets by the marine sponge Halichondria panicea Pallas (1766). J Exp Mar Biol Ecol 129:81-94

Yager PL, Nowell ARM, Jumars PA (1993) Enhanced deposition to pits: a local food source for benthos. J Mar Res 51 . $209-236$

Ziebis W (1991) Experimente im Strömungskanal zum Einfluß der Makrofauna auf den bodennahen Partikeltransport. MSc thesis, Unuversity of Kiel

Manuscript received: August 8, 1996

Revised version accepted: May 16, 1997 